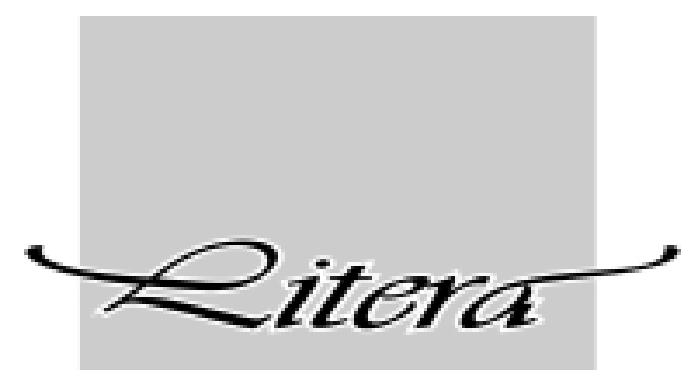

\title{
GEDIGTE
}

Heilna du Plooy

Nanagvers

IV Wind

Lyfwysheid

Hans du Plessis

Dissie son

Oeroe my

Psalm 128

Ronel Nel

[die evolusie van verwondering]

[palm psalm ii]

\section{Litera-prys 2000}

Die Redaksie van Literator kondig met genoeë aan dat die Litera-prys vir die beste bydraes vir 2000 toegeken is aan T.T. Cloete as "gevestigde" digter vir sy gedig "Ysberge" en aan Etienne Terblanche as "debutant" vir al sy bydraes.

It is with pleasure that the Editorial Board of Literator can announce that the Litera Prizes for the best contributions for 2000 have been awarded to T.T. Cloete as "established" writer for his poem "Ysberge" and to Etienne Terblanche as "debutant" for all his contributions.

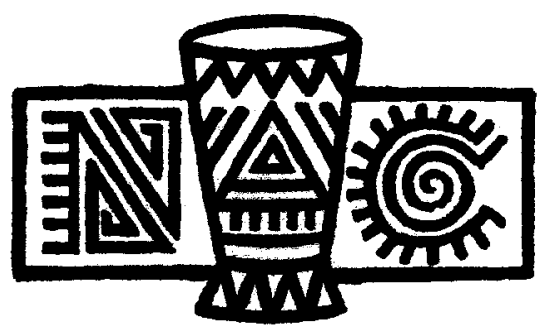

NATIONAL ARTS COUNCIL

OF SOUTH AFRICA

Die rubriek Litera word finansieel gesteun deur die Nasionale Kunsteraad /

The section Litera is financially supported by the National Arts Council/ 


\section{Rubriek vir skeppende werk}

Litera is ' $n$ rubriek vir die publikasie van skeppende werk in al die tale wat gewoonlik in Literator gebruik word. Die Redaksie wil daarmee 'n geïntegreerde beeld skep van die verskeidenheid nuwe skryfwerk wat SuidAfrikaanse skrywers kan bied.

Die Redaksie kan met vreugde aankondig dat 'n kontantprys toegeken gaan word aan die beste bydraes in die loop van 'n jaar. Een prys sal toegeken word vir die beste bydrae deur 'n debutant en 'n tweede vir die beste bydrae deur 'n meer gevestigde skrywer.

Skrywers word daarom uitgenooi om korter skeppende werk voor te lê vir plasing in hierdie rubriek. Dit kan gedigte of kortverhale wees, maar drama- of romanfragmente en eksperimentele tekste is ook welkom. Bydraes word deur die redaksie gekeur, maar geen korrespondensie kan daaroor gevoer word nie. Vier kopieë van elke bydrae, in dubbelspasiëring getik, moet voorgelê word. Die naam en adres van die insender moet regs bo-aan die eerste blad van gekramde tekste en op elke los vel vermeld word. Verstrek ook 'n telefoonnommer, faksnommer en e-posadres waar u bereik kan word.

Stuur alle bydraes aan die Hoofredakteur, Literator (629), Buro vir Wetenskaplike Tydskrifte, Privaatsak X6001, Potchefstroom 2520.

\section{Section for creative writing}

Litera is a section for the publication of creative writing in all the languages that Literator usually caters for. Through this section the Editorial Board want to present an integrated image of the diversity of new writing by South Africans.

The Editorial Board is pleased to announce that a cash prize will be awarded for the best contributions for a specific year. One prize will be awarded for the best debut contribution and one for the best contribution by a more established author.

Writers are therefore invited to submit shorter creative work for publication in this section. Poems and short stories are welcome, but also play and novel fragments and experimental texts. Contributions are refereed by the Editorial Board, but we cannot enter into correspondence about the work submitted. Four copies of each contribution, typed in double spacing, should be submitted. The name and address of the author should appear at the top right of the first page of stapled text and on every loose sheet sent in. Please include a telephone number, a fax number and an e-mail address where you can be contacted.

Send all contributions to the Editor-in-Chief, Literator (629), Bureau for Scholarly Journals, Private Bag X6001, Potchefstroom 2520. 


\section{Reglement: Litera-pryse vir kreatiewe skryfkuns}

1. Die Redaksie van Literator ken jaarliks, uit geld bewillig deur die Nasionale Kunsteraad, twee pryse toe vir die beste bydraes vir 'n kalenderjaar in die rubriek "Litera".

2. Hierdie pryse sal bekendstaan as die Litera-pryse vir kreatiewe skryfkuns.

3. Die waarde van die pryse hang af van die grootte van die toekenning deur die Nasionale Kunsteraad.

4. Twee pryse word toegeken, een vir skrywers wat reeds 'n bundel in die betrokke genre gepubliseer het, en een vir skrywers wat nog nie 'n bundel gepubliseer het nie (d.w.s. wat as debutante beskou word).

5. Die Redaksie bepaal aan wie die pryse toegeken word, en die Redaksie kan buitebeoordelaars gebruik om met die beoordeling behulpsaam te wees. Die beslissings van die Redaksie is finaal en geen korrespondensie sal daaroor gevoer word nie.

6. Die Redaksie behou hom die reg voor om vir 'n spesifieke jaar of vir 'n spesifieke kategorie nie 'n prys toe te ken nie of om 'n prys onder verskillende skrywers te verdeel.

7. Die name van die skrywers aan wie die pryse toegeken is, sal bekendgemaak word in die eerste uitgawe van Literator van die daaropvolgende kalenderjaar.

\section{Rules: Litera Prizes for Creative Writing}

1. The Editorial Board of Literator yearly awards two prizes for the best contributions for a calendar year in the section "Litera" from money granted by the National Arts Council.

2. These prizes will be known as the Litera Prizes for Creative Writing.

3. The size of the prizes will depend on the grant received from the National Arts Council.

4. Two prizes will be awarded, one for writers who have already published a collection in the genre concerned, and one for writers who have not yet published a collection (that is, who are regarded as making their début).

5. The Editorial Board determines to whom the prizes will be awarded, and it may appoint external judges to help with the evaluation of contributions. The decisions of the Editorial Board are final and no correspondence on this matter will be entered into.

6. The Editorial Board reserves the right to make no award for a particular year or in a particular category or to divide a prize among different authors.

7. The names of the authors to whom the awards have been made, will be published in the first issue of Literator of the subsequent calendar year. 


\section{Heilna du Plooy}

\section{Nanagvers}

Nanags wakker flits die helder beeld.

Van daardie dromerige kind. Wat met

'n piepklein gieter water op die varings

gooi. Nat varings op die rooigeverfde

stoep. Die stoep met skaduwee.

En rondom lê die sondeurweekte werf.

Gebaken en geborge leef die kind in son

en sien. Die miere op die fyn gruisgrond.

Die blink swart kat se grasgroen oog.

In hierdie klein en eindelose plek

herken die kind iets wonderliks

en dink dis doodgewoon.

Ook in die nanag die gedagtes

oor die sterkes. Dié wat so groot

kan doen. Wat alles makmaak, alles tem.

Wat skik en herskik, dit wat was, wat is

en dit wat kom. Dié wat die verste

einders klein en naby dink. Hul lê

hul hand op elke afgeleë ding.

Oneindig is dié eiesinnigheid

wat strak maak en beklem.

Soms nanags flits daar dan

die sku vis in 'n donker dam.

Daar ís iets klein en eindeloos.

lets ís volkome rond. 'n Kind se oog

sien wonders in die grond. 
Heilna du Plooy

\section{Wind}

Bedink dit. Dat die wind onsigbaar is.

Dat groot volumes lug versamel

en begin beweeg. Geweldig.

Oor die aarderonding stort

sonder om gesien te word.

Bedink dit. Dat die wind deurskynend is.

Dat die geweld eers sigbaar word

in wat die wind kan aanrig. In die puin.

In die gebreekte bome. Stortreën.

Sonder dat die wind self sienlik is.

Bedink ook dit. Siklone en tifone, die tornado's, die orkane dra

die mooiste vrouename. Die winde

wat beroering bring, is groots.

En is onsienlik. Is ook vroulik.

Misgekyk en onverreken

word die winde sterk.

Versamel debris. Self

verstom oor die diep krag

waarmee hul furie sigbaar word.

(Uit die bundel In die landskap ingelyf wat eersdaags verskyn by Protea Boekhuis.) 


\section{Heilna du Plooy}

\section{Lyfwysheid}

In bronne van gesag kan almal daarvan lees.

Vir eeue spook die filosowe - meestal mans -

met daardie ondeurgrondelike vraag:

die verhouding van die liggaam tot die gees.

Plato sien die siel toevallig aangeland

in die essensiële kerker van die lyf.

Augustinus vind God in sy dink,

kyk lyfloos al hoe meer na binne in.

Aquinas skei die vorm van die materie, Descartes die denke van die vlees.

By Hegel, Kant en Heidegger, selde hoe, bly liggaam altyd sekondêr tot gees.

Maar as die houer vol word en wil stort tot in diep lag, diep huil, in daardie krag waarmee 'n vrou geboorte skenk, dink ek en het ek lief tot in my naels en elke haar se punt. Tuimelend. In die ekstase in. Daarom, uiteindelik, is ek.

(Uit die bundel In die landskap ingelyf wat eersdaags verskyn by Protea Boekhuis.) 


\section{Hans du Plessis}

\section{Dissie son}

Jille kamma dink ek isse bietjie te bryn, sos hierie niewe soorte matjiesgoedgordyn: ma my broer-goed het aspris vi my allenig oppie jaartse gelat agterbly, toe't ek half sleg agter my eige drywe gekyk, nou sien ek vedag eers wee hoelat ek lyk.

Ek is altemit 'n bietjie bryn, ma mooi sosse skemerdyn.

\section{Oeroe my}

Ek wens my liefling kom na my toe, lat ekkie syker van hy se lippe proe, ennie soetlikgeit vannie dryf ytie ryp jaartse van hy se lyf. Eentlik issit hy wat my so oeroe en saf klei rooi oor my jippe vryf die anner vrouense hou hoeka hille se honger lyfte na hom toe yt.

[Uit: Boegoe vannie liefde, Griekwahooglied Verskyn September by Lapa-uitgewers.] 


\section{Hans du Plessis}

\section{Psalm 128}

Vir Albert en Albertha

31 Oktober 2001

Dit gat goed mettie man wattie Jirre dien en goeterse doen sos wattie Jirre vi ons vra. Jy sallie lammerse van jou se werklikheid sien, en gelik en voorspoed sos grashout teen jou dra. Jou se vrou isse dryf wat soeterder troste gjee, jou se kjennerse sit ommie skerm sosse sierkaree. Kyk, só wôre 'n man geseën wattie Jirre dien.

Maggie drippelse van Postmasburg op jou reën en jou oudag sien wa lattie Jirre vi Griekwaland seën. En mag jy jou se agterkjennerse ok nou ken, en sien hoelattie vrede in onse land in wen. 


\section{Ronel Nel}

\section{[die evolusie van}

\section{verwondering]}

hoe het ons ontmoet

in 'n oerpoel het ek gevoel

ek dink ek onthou dit was soel

ons was twee amoebas wat mekaar aangeraak het

ingesluk het aan 'n klip vasgeslik het

en 'n nuwe strain lewe gemaak het

of was ek die mos op jou rots

of was jy die kern van my nuwe saad

'n jong boom op ou ou grond

en het ons albei daar rond gedwaal gedroom

gesmag om na die volgende orde te verhuis

en daar te woon

as dier of as voel of as mens

ek weet nou dit was beslis

as wens

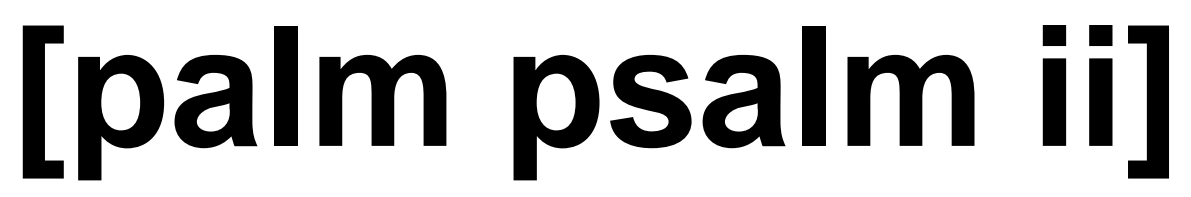

hond blaf, ons bluf

iewers klink die diep gesang

van die maan se swanger gang

en o, my lief, in 'n kleindorpse katedraal

is ons albei immense

en is ons albei verdwaal 